\section{Loyalitas Kreativitas \\ Aldi Masyarakat Kreatif}

P-ISSN 2722-2101, E-ISSN 2722-4201

Program Studi Ekonomi Manajemen Universitas Pamulang

Jurnal LOKABMAS Kreatif Vol. 01, No. 01, Hal. 36 - 49

Email:jurnalkreatif.manajemen@gmail.com

\title{
PELATIHAN MANAGEMEN PEMASARAN DAN KEUANGAN PADA UMKM BANGKIT SEJAHTERA DUSUN KEDUNG BUWENG WUKIRSARI DALAM MENINGKATKAN PEREKONOMIAN
}

\author{
Khotimatus Sadiyah, Wiwik Hasbiyah AN, Liana Dwi Septiningrum \\ Dosen Ekonomi Fakultas Ekonomi Universitas Pamulang \\ Email: diyah.khotimatus@gmail.com,wiwik.hasbiyah@yahoo.com
}

\begin{abstract}
ABSTRAK
Pemasaran merupakan elemen penting menjalankan sebuah bisnis. Banyak pelaku bisnis yang meluangkan waktunya untuk memikirkan metode pemasaran apa yang tepat agar barang yang dijualnya laku di pasaran, karena sukses tidaknya bisnis bergantung pada metode/cara pemasaran apa dan bagaimana yang dilakukan oleh pelaku usaha khususnya para pelaku UMKM. Pengabdian kepada masyarakat ini berjudul "Pelatihan Managemen Pemasaran dan Keuangan pada UMKM Bangkit Sejahtera Dusun Kedung Buweng Wukirsari Dalam Meningkatkan Perekonomian".

Salah satu UMKM pada program kegiatan Pengbdian Kepada Masyarakat (PKM) ini adalah UMKM Bangkit Sejahtera dusun Kedung Buweng Desa Wukirsari Kecamatan Imogiri -Bantul. Pelaku usaha mengeluhkan masalah utama yang dihadapi mitra ialah kurangnya pengetahuan dalam memasarkan produknya baik secara konvensional (offline) maupun secara online, khususnya ecommerce dan permasalahan lainnya yaitu minimnya pengetahua tentang manajemen keuangan yang baik. Pemasaran yang dilakukan UMKM Bangkit Sejahtera pada umumnya menggunakan pemasaran offline yaitu dengan menjajakan produknya di warung-warung penduduk dusun Kedung Buweng. Minimnya pengetahuan tentang pemasaran produk berdampak pada rendahnya sales volume pada aktifitas penjualan yang berakibat pada penurunan omzet pelaku usaha UMKM Bangkit Sejahtera.

Berdasarkan permasalahan utama mitra yaitu kurangnya informasi manajemen pemasaran dan manajemen keuangan maka solusi yang ditawarkan kepada mitra ialah dengan memberikan 3 pelatihan yang terdiri dari pelatihan kegiatan pemasaran online, memberikan pelatihan kegiatan pemasaran offline, dan memberikan pelatihan manajemen keuangan. Dengan metode yang digunakan adalah ceramah, Tanya jawab, dan simulasi.

Adapun target luaran program ini adalah dapat membantu mitra bisnis/ pelaku UMKM Bangkit Sejahtera dalam memasarkan produknya sehingga dapat meningkatkan pendapatan/ omset para pelaku bisnis. sehingga mitra bisnis yang memiliki modal tidak terlalu banyak dapat menggunakan modalnya secara efesien dan efektif dengan cara melakukan pemasaran/ marketing baik offline dan online secara tepat.
\end{abstract}

\section{Kata Kunci: Manajemen, Pemasaran, Produk, Keuangan, UMKM}

\begin{abstract}
ABSTRAC
Marketing is an important element of running a business. Many business people take the time to think about what marketing methods are right so that the goods they sell sell in the market, because the success or failure of the business depends on what methods / ways of marketing and how that is done by business actors, especially the UMKM. This community service is entitled " Marketing and Financial Management Training at UMKM Bangkit Sejahtera in Kedung Buweng Wukirsari Hamlet in Improving the Economy ".

One of the UMKM in the Community Service Program (PKM) is the UMKM Bangkit Sejahtera in the Kedung Buweng sub-village, Wukirsari Village, Imogiri -Bantul District. Business actors complain that the main problem faced by partners is the lack of knowledge in marketing their products
\end{abstract}




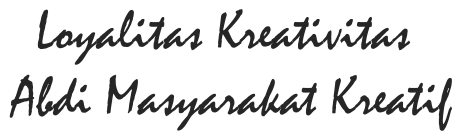

P-ISSN 2722-2101, E-ISSN 2722-4201

Program Studi Ekonomi Manajemen Universitas Pamulang

Jurnal LOKABMAS Kreatif Vol. 01, No. 01, Hal. 36 - 49

Email:jurnalkreatif.manajemen@gmail.com

both conventionally (offline) and online, especially e-commerce and other problems, namely the lack of knowledge about good financial management. Marketing done by Bangkit Sejahtera UMKM generally uses offline marketing, namely by selling its products in the stalls of residents of Kedung Buweng hamlet. The lack of knowledge about product marketing has an impact on the low sales volume on sales activities which results in a decrease in the turnover of Bangkit Sejahtera UMKM entrepreneurs.

Based on the main problems of partners, namely the lack of marketing management and financial management information, the solution offered to partners is to provide 3 training courses consisting of training in online marketing activities, providing training in offline marketing activities, and providing financial management training. The methods used are lectures, questions and answers, and simulations.

The target of this program output is to be able to help Bangkit Sejahtera business partners in marketing their products so as to increase the income / turnover of business people. so business partners who have not too much capital can use their capital efficiently and effectively by marketing both offline and online appropriately.

\section{Keywords: Management, Marketing, Products, Finance, UMKM}

\section{PENDAHULUAN}

Konsep pemasaran mengatakan bahwa kunci untuk mencapai tujuan organisasi terdiri dari penentuan kebutuhan dan keinginan pasar sasaran serta memberikan kepuasaan yang diharapkan secara lebih efektif dan efisien dibandingkan para pesaing. Perkembangan tehnologi saat berkembang sangat pesat, sehingga mau tidak mau masyarakat harus mengikuti perkembangan tehnologi tersebut, bila tidak mengikuti akan ketinggalan. Penggunaan social media adalah alat pemasaran yang paling ampuh karena semua orang dari berbagai latar belakang yang berbeda, sangat aktif menggunakannya. Dengan social mediapelaku usaha dapat menjalin interaksi secara luas dengan berbagai kalangan, dengan yang murah dan sesuai untuk memasarkan produk mereka, sehingga apa yang ditawarkan memiliki peluang besar untuk terjual.Salah satu Usaha atau bisnis lewat internet (dengan menggunakan elektronik) ini sering diseut dengan electronic commerce (E-Commerce) atau Electronic business (E-Business). ECommerce adalah suatu proses berbisnis dengan memakai teknologi elektronik yang menghubungan antara perusahaan, konsumen dan masyarakat dalam bentuk transaksi elektronik dan pertukaran/ penjualan barang, servis, dan informasi secara elektronik.
Usaha Mikro Kecil Menengah atau UMKM merupakan suatu usaha yang dibentuk dan diselenggarakan oleh masyarakat, kalangan menengah kebawah. Dimana usahanya adalah usaha rumahan. Meskipun usaha kecil dan menengah ini memiliki skala kecil, keberadaan usaha ini di tengah masyarakat memiliki manfaat yang besar baik bagi masyarakat dan juga sebagai salah satu pendorong manfaat pembangunan ekonomi Negara. Perkembangan usaha kecil dan menengah tentunya sangat berpengaruh pada negara yang masih berkembang seperti negara Indonesia. Hal yang lebih penting adalah menumbuhkan jiwa wirausaha dimasyarakat,sehingga dapat menyerap lapangan pekerjaan dan mengurangi jumlah pengangguran.

Usaha mikro kecil dan menengah (UMKM) Bangkit Sejahtera merupakan komunitas bagi para pelaku usaha mikro kecil dan menengah yang berada di daerah Dusun Kedung Buweng Desa Wukirsari Kecamatan Imogiri. keterbatasan informasi strategi pemasarana dan manajemen keuangan yang masih belum baik membuat para pelaku usaha di dusun kedung buweng kurang memaksimalkan potensi yang ada. Hal ini karena strategi pemasaran masih cenderung konvensional yaitu dengan menjual hasil produk di warung-warung depan rumah pelaku usaha, selain itu proses 
Loyalitas Kreativitas
Aldi Masyarakat Kreatif
P-ISSN 2722-2101, E-ISSN 2722-4201

Program Studi Ekonomi Manajemen Universitas Pamulang

Jurnal LOKABMAS Kreatif Vol. 01, No. 01, Hal. 36 - 49

Email:jurnalkreatif.manajemen@gmail.com pengemasan produk yang kurang menarik yaitu produk hanya di kemas dengan plastik putih dengan perekat streples, selain itu tidak adanya keterangan bahan-bahan dan tanggal kadarluarsa produk pada kemasan produk. Strategi pemasaran yang kurang tepat seringkali membuat pelaku usaha dihadapkan pada penolakan pasar yang membuat pelaku usaha mengalami penurunan dalam memasarkan usahanya yang berpengaruh pada keuangan pelaku usaha. Hal ini di dukung dengan data yang publikasikan pemerintah kabupaten bantul untuk desa wukirsari yaitu pada bidang pemberdayaan masyarakat yang bersumber dari potret desa bahwa "Pelatihan usaha ekonomi, pertanian, perikanan, dan perdagangan, yaitu: Gapoktan, UMKM, pelatihan penggunaan bahan bekas, Kopwan, dan Puap menjadi masalah dan isu strategis desa"(https://wukirsari.bantulkab.go.id)

Berdasarkan uraian masalah tersebut, maka disepakati bahwa terdapat masalah utama, yaitu kurangnya informasi manajemen pemasaran dan manajemen keuangan UMKM Bangkit Sejahtera Dusun Kedung Buweng Desa Wukirsari Kecamatan Imogiri Bantul. Kegiatan Pengabdian Kepada Masyarakat (PKM) yang dilakukan oleh beberapa dosen dari fakultas ekonomi Prodi Akuntansi, Universitas Pamulang. Kegiatan ini merupakan bentuk keterlibatan perguruan tinggi dalam melaksanakan tridharma perguruan tinggi dan memberikan pemahaman dan sosialisasi kepada pelaku UMKM mengenai strategi-strategi pemasaran yang tepat agar dapat mengoptimalkan profit yang diinginkan, sehingga terbentuklah kegiatan pengabdian kepada masyarakat dengan judul" Pelatihan Managemen Pemasaran Dan Keuangan Pada UMKM Bangkit Sejahtera Dusun Kedung Buweng Wukirsari Dalam Meningkatkan Perekonomian"

Adapun sasaran pengabdian yang kami tuju yaitu Anggota UMKM Bangkit Sejahtera Dusun Kedung Buweng Desa Wukirsari Kecamatan Imogiri Bantul. Adapun target luaran program ini adalah artikel ilmiah yang dipublikasikan melalui jurnal berISSN, dan membantu mitra bisnis/ pelaku UMKM Bangkit
Sejahtera dalam memasarkan produknya sehingga dapat meningkatkan pendapatan/ omset para pelaku bisnis. sehingga mitra bisnis yang memiliki modal tidak terlalu banyak dapat menggunakan modalnya secara efesien dan efektif dengan cara melakukan pemasaran/ marketing baik offline dan online secara tepat.

\section{RUMUSAN MASALAH}

Dengan mempertimbangkan latar belakang yang telah diutarakan di atas maka rumusan masalah pengabdian masyarakat adalah:

1. Memberikan pemahaman tentang Manajemen pemasaran dan keuangan pada UMKM Bangkit Sejahtera

2. Memberikan pelatihantentang market place guna meningkatkan hasil pemasaran

3. Meningkatkan kemampuan setiap anggota UMKM dalam pengeloaan keuangan perusahaan

\section{TUJUAN PELAKSANAAN}

Tujuan kegiatan pengabdian masyarakat ini adalah Agar dapat membantu Para anggota UMKM Bangkit Sejahtera dalam meningkatkan pendapatan dan pengelolaan keuangannya Secara rinci, tujuan kegiatan ini diantaranya untuk :

1. Memberikan pemahaman dan pelatihan kepada para peserta dikalangan anggota UMKM Bangkit Sejahtera tentang pentingnya manajemen pemasaran yang baik melalui marketing mix

2. Memberikan pelatihan pemasaran online yang dibutuhkan dimasa sekarang melalui marketplace seperti tokopedia dan lazada

3. Memberikan pemahaman kepada anggota UMKM Bangkit Sejahtera tentang keuntungan manfaat dalam mengatur mengelola keuangan yang baik dalam berwirausaha.

\section{TINJAUAN PUSTAKA}

\section{UMKM}

Usaha Mikro Kecil dan Menengah merupakan suatu usaha yang dibentuk dan diselenggarakan oleh masyarakat, yang bukan berasal dari kalangan atas atau orang kaya. Pada umumnya, terbentuknya usaha ini berasal dari 
ide satu orang atau beberapa orang dalam suatu organisasi masyarakat. Meskipun usaha kecil dan menengah ini memiliki skala kecil, keberadaan usaha ini di tengah masyarakat memiliki manfaat yang besar baik bagi masyarakat dan juga sebagai salah satu pendorong manfaat pembangunan ekonomi Negara.

Perkembangan usaha kecil dan menengah sangat memiliki pengaruh yang besar pada negara, terutama pada negara yang masih berkembang. Dalam suatu negara manfaat usaha kecil dan menengah berperan dalam mengembangkan masyarakat mandiri dan meningkatkan pertumbuhan ekonomi. Dalam usaha ini masyarakat berperan langsung sebagai penggagas, pelaksana dan pengendali. Aspek lain yang juga bermanfaat bagi masyarakat sekitarnya adalah adanya manfaat jiwa wirausaha, karena jiwa wirausaha yang dimiliki masyarakat dapat membantu berkembangnya masyarakat mandiri dan secara tidak langsung dapat mengurangi jumlah pengangguran.

Di bawah ini adalah beberapa manfaat atau fungsi dari usaha kecil dan menengah bagi suatu negara:

1. Terbukanya lapangan pekerjaan

Salah satu manfaat usaha bagi masyarakat dengan usaha kecil dan menengah ini dapat membuka kesempatan kerja yang lebih luas pada masyarakat. Dengan adanya usaha ini, dapat mengurangi jumlah pengangguran di tengah masyarakat. Apalagi usaha ini tidak memerlukan spesifikasi pendidikan yang tinggi. Sehingga masyarakat dengan pendidikan rendah bahkan tidak mengenyam pendidikan pun dapat melakukan usaha, asal memiliki keterampilan atau sudah terlatih.

2. Dapat meningkatkan angka produk domestik bruto

Produk domestik bruto merupakan sebuah nilai makro ekonomi suatu negara dilihat dari kemampuan negara tersebut dalam melakukan produksi suatu jasa atau barang dalam jangka waktu tertentu. Hal ini akan menunjukkan seberapa besar kemampuan ekonomi pada suatu negara. Usaha kecil dan menengah adalah salah satu penyumbang pajak negara yang cukup besar, karena keberadaannya yang banyak di tengah masyarakat. Sehingga manfaat bisnis sendiri atau mandiri masyarakat ini secara tidak langsung membentuk dalam peningkatanpertumbuhan, pembangunan dan kemajuan negara.

3. Meningkatkan ekonomi Negara

Usaha kecil dan menengah di tengah masyarakat keberadaannya semakin marak, karena mudah untuk dimulai dan pelaksanaannya yang fleksibel. Manfaat usaha kecil dan menengah secara langsung adalah mengangkat perekonomian masyarakat menengah ke bawah. Usaha ini memiliki manfaat yang lebih besar yaitu secara tidak langsung dapat mendukung pertumbuhan ekonomi negara. Dengan adanya usaha kecil dan menengah dapat meningkatkan pendapatan nasional yang diperoleh negara.

4. Solusi usaha untuk masyarakat kecil

Manfaat membuka usaha kecil dan menengah ini adalah sebagai salah satu solusi perekonomian masyarakat menengah ke bawah, yang memiliki latar belakang pendidikan kurang walaupun faktanya ada pelaku usaha ini yang memiliki pendidikan tinggi. Masyarakat dapat memulai usaha ini sesuai dengan kemampuannya tanpa ada persyaratan khusus. Untuk memajukan usaha ini, pemerintah juga telah memberikan fasilitas seperti pelatihan, modal atau dalam pengembangan usaha.

Dari beberapa manfaat usaha kecil dan menengah di atas dapat disimpulkan bahwa keberadaan usaha ini di tengah masyarakat tidak hanya sebatas pengembangan perekonomian masyarakat saja. Namun juga meliputi banyak aspek yang juga bermanfaat bagi masyarakat sekitarnya dan dalam membantu pertumbuhan pembangunan ekonomi negara. Manfaat jiwa wirausaha di sini sangatlah penting, karena jiwa wirausaha yang dimiliki masyarakat dapat membantu berkembangnya masyarakat mandiri dan secara tidak langsung dapat mengurangi jumlah pengangguran.

\section{Pemasaran}

Pemasaran merupakan elemen penting dalam menjalankan sebuah bisnis. Banyak pelaku bisnis yang meluangkan 
Loyalitas Kreativitas
Aldi Masyarakat Kreatif
P-ISSN 2722-2101, E-ISSN 2722-4201

Program Studi Ekonomi Manajemen Universitas Pamulang

Jurnal LOKABMAS Kreatif Vol. 01, No. 01, Hal. 36 - 49

Email:jurnalkreatif.manajemen@gmail.com waktunya untuk memikirkan metode/ cara/ strategi pemasaran apa yang tepat agar barang yang dijualnya laku di pasaran dan omsetnya cepat meningkat. Hal ini berpengaruh terhadap sukses tidaknya bisnis karena bergantung pada metode/ cara pemasarannya.berikut beberapa hal penting yang kalau diterapkan setidaknya bisa mendatangkan konsumen, diantaranya:

1. Spesifikasi Produk

Spesifikasi produk merupakan poin penting sebelum menjual barang. Spesifikasi berisi informasi detail mengenai aspek dan bahan dalam pembuatan produk. Spesifikasi produk wajib disertakan pada kolom informasi produk. Tujuannya agar calon pembeli bisa membayangkan seperti apa produk yang akan dibelinya. Pembeli juga dapat mempertimbangkan antara harga dan kualitas produk. Apabila produk berkualitas, pembeli pasti tidak berkeberatan mengeluarkan uang yang banyak demi produk tersebut.Adanya spesifikasi juga sebagai perbandingan antara produk yang Anda jual dan produk dari brand lain. Dengan demikian, pembeli juga bisa mengetahui kelebihan dan kelemahan dari setiap produk.

2. Segmentasi Pasar

Keadaan ekonomi sangat berpengaruh terhadap daya beli masyarakat. Konsumen yang berpenghasilan tinggi cenderung bersikap konsumtif dan tidak terlalu memedulikan harga barang. Asalkan barang tersebut berkualitas dan unik, harga bukanlah masalah.Berbeda dengan konsumen yang berpenghasilan rendah, harga menjadi patokan saat memutuskan apakah melakukan pembelian atau tidak.Selain keadaan ekonomi, faktor selera dan kebutuhan juga menjadi poin yang membedakan konsumen satu dan konsumen lainnya.

Adanya segmentasi pasar akan membantu untuk menargetkan kepada siapa produk tersebut harus dijual dan bagaimana cara agar informasi mengenai produk tersebut sampai ke konsumen.

3. Menentukan Target Pemasaran

Target pemasaran berkaitan dengan kepada siapa produk tersebut akan dijual. Sebelum menjual produk, ada baiknya jika pelaku bisnis mengamati budaya masyarakat saat membeli barang.Pada poin ini, pelaku bisnis harus melakukan pengamatan langsung di lapangan. Lakukan wawancara singkat dengan para konsumen.Setelah Anda mendapatkan informasi mengenai target pemasaran secara lengkap, maka pelaku usaha dapat segera membuat produknya.

Susunlah strategi apa yang harus ditetapkan agar produk tersebut laku dijual di pasaran. Lakukan promosi secara bertubi-tubi dengan menempelkan brosur atau iklan di media sosial.Keberhasilan bisnis juga diukur dari loyalitas konsumen untuk berbelanja di tempat Anda. Karena itu, pikirkanlah bagaimana cara untuk mencuri perhatian konsumen dan menjaga loyalitas mereka terhadap bisnis.

4. Tempat Pemasaran

Setelah mengetahui siapa yang menjadi sasaran penjualan, kini saatnya menentukan tempat pemasaran. Tempat pemasaran haruslah sesuai dengan target pemasaran.Jika targetnya pasarnya anak muda dan kalangan produktif, alangkah baiknya dipasarkan di area sekitar kampus atau secara online.

5. Promosi

Keempat poin di atas tentu akan sukses jika disertai dengan promosi yang tepat. Ada banyak media yang dapat difungsikan sebagai wadah untuk promosi. Misalnya, koran, majalah, televisi, radio, dan sosial media.

\section{Manajemen Keuangan}

Pengertian Manajemen Keuangan Menurut Horne dan Wachowicz Jr. (2012:2) dalam bukunya yang berjudul Fundamentals of Financial Management yang telah di alih bahasa menjadi Prinsip-prinsip Manajemen Keuangan mengemukakan bahwa: "Manajemen keuangan berkaitan dengan perolehan aset, pendanaan, dan manajemen aset dengan didasari beberapa tujuan umum". Sedangkan menurut Irham Fahmi (2013:2), mengemukakan bahwa: "Manajemen Keuangan merupakan penggabungan dari ilmu dan seni yang membahas, mengkaji dan menganalisis tentang 
bagaimana seorang manajer keuangan dengan mempergunakan seluruh sumberdaya perusahaan untuk mencari dana, mengelola dana dan membagi dana dengan tujuan memberikan profit atau kemakmuran bagi para pemegang saham dan suistainability (keberlanjutan) usaha bagi perusahaan."

Menurut Bambang Riyanto (2001:6) menyatakan pada dasarnya manajemen keuangan memiliki fungsi yang terdiri dari : 1 . Fungsi Penggunaan atau Pengalokasian Dana dimana dalam pelaksanaannya manajemen keuangan harus mengambil sebuah keputusan investasi ataupun pemilihan alternatif investasi. 2. Fungsi Perolehan Dana yang juga sering disebut sebagai fungsi mencari sumber pendanaan dimana dalam pelaksanaannya manajemen keuangan harus mengambil sebuah keputusan pendanaan atau pemilihan alternatif pendanaan (financing decision). 3 Pengertian fungsi manajemen keuangan yaitu sebagai pedoman bagi manajer perusahaan dalam setiap pengambilan keputusan yang dilakukan demi kelancaran perusahaannya terutama dalam hal manajemen keuangannya. Manajemen keuangan dapat digambarkan dalam bentuk laporan keuangan.

Laporan keuangan menggambarkan kondisi keuangan dan hasil usaha suatu perusahaan pada saat tertentu atau jangka waktu tertentu. Bagi para analis, laporan keuangan merupakan media yang paling penting untuk menilai prestasi dan kondisi ekonomis suatu perusahaan. Laporan keuangan menjadi bahan sarana informasi (screen) bagi analis dalam proses pengambilan keputusan. Laporan keuangan dapat menggambarkan posisi keuangan perusahaan, hasil usaha perusahaan dalam suatu periode, dan arus dana (kas) perusahaan dalam periode tertentu.

\section{METODE PELAKSANAAN}

Dalam pelaksanaan kegiatan ini metode yang dilakukan adalah ceramah, tanya jawab, dan simulasi. Pada sesi ceramah yang disampaikan oleh : Ibu Wiwik Hasbiyah AN, S.Hi, M.A, selaku narasumber membahas mengenai manajemen pemasaran yang membahas tentang pengertian, tujuan dan segmentasi pemasaran. Pada sesi tanya jawab, membahas permasalahan omset pelaku usaha yang belum stabil, karena terdampak minimnya modal usaha, omset yang jauh dibawah harapan, adanya kompetitor yang juga menjual produk yang sama dengan pelaku usaha binaan, minimnya pengetahuan tentang aplikasi layanan online digital, penolakan pasar karena pasar sudah membeli produk yang sama pada layanan ecommerce lain. Pada sesi diskusi, pelaku usaha binaan diberikan pemahaman tentang aplikasi yang dibutuhkan dalam pemasaran produk secara digital dan pelatihan dalam menggunakan perangkat maupun aplikasi sosial media, sehingga dari aplikasi digital pelaku usaha dapat membuat atau menggunakan salah satu atau beberapa situs penjualan online. Dilanjutkan dengan program pelatihan pemasaran online pada pelaku usaha seperti pada whatsapp, facebook, instagram, serta situs penjualam online lainnya. Salah satu simulasi market place pemasaran online yaitu pada market place tokopedia yang di bantu oleh ibu Liana Dwi Septiningrum, S.E, M.M, Ibu Khotimatus Sadiyah, S.Si, M.M, Ibu Dina Novita, S.E, M.M dan Bapak Julian Muhammad Hasan, S.Sos, M.A.

\section{PRA KEGIATAN}

Pelaksanaan program kegiatan Pengabdian Kepada Masyarakat (PKM) ini melalui beberapa tahapan yang telah dilaksanakan, antara lain dapat digambarkan dalam alur berikut:

1. Tahap Persiapan

a. Kegiatan Observasi dan Perizinan

Observasi dilakukan dengan melakukan survey pada lokasi yang akan dijadikan kegiatan Pengabdian Kepada Masyarakat (PKM) yakni Dusun Kedung Buweng kecamatan Wukirsari Kabupaten Bantul Yogyakarta. Survey dilakukan 3 kali untk menentukan titik yang tepat yang akan dijadikan sebagai point kegiatan. Dalam tahapan perizinan para dosen berkordinasi dengan pihak terkait, seperti: Ketua RT Dusun kedung Buweng Kecamatan Wukirsari Bpk Erwan Rudianto dimana kegiatan PKM akan dilaksanakan.

2. Penyusunan RAB 
Rencana Anggaran dan Belanja dipersiapkan dalam hal pembelian belanja bahan seperti: Honor narasumber, cinderamata/ plakat, konsumsi, sertifikat, materi, pembuatan jurnal dan door prize serta beberapa peralatan lain nya yaitu: tempat pelatihan, sound system, laptop dan LCD proyektor.

3. Pengajuan Proposal

Proposal kegiatan PKM diajukan pada tanggal 22 September 2019 dan setelah melalui proses review, disetujui oleh Ketua LPPM Bapak Ali Madinsyah pada tanggal 9 Oktober 2019.

4. Tahap Implementasi/ pelaksanaan kegiatan

Setelah melakukan koordinasi maka dilaksanakan kegiatan pengabdian kepada masyarakat pada hari Sabtu,12 Oktober 2019 s.d Senin, 14 Oktober 2019.

\section{HASIL DAN PEMBAHASAN}

Kegiatan Pengabdian Masyarakat ini dilakukan di balai warga Dusun Kedung Buweng Desa Wukirsari kecamatan Bantul Yogyakarta. Kegiatan pengabdian ini dihadiri oleh anggota UMKM Bangkit Sejahtera yang anggotanya terdiri dari ibu-ibu rumah tangga di dusun kedung buweng yang selain berprofesi sebagai ibu rumah tangga juga mayoritas bekerja sebagai penghasil produk wedang eweh kemasan. Kegiatan ini disambut positif oleh ibuibu anggota UMKM Bangkit Sejahtera karena kurangnya pemahaman mereka akan pemasaran online. Pada hasil pengamatan yang dilakukan oleh para dosen Universitas pamulang, ditemukan beberapa masalah yaitu (1) pengemasan produk pada umumnya masih konvensional yaitu dengan memanaskan plastic pada api lilin hal ini terkendala pada tidak adanya mesin press untuk mengemas hasil produk. (2) Pengemasan produk yang konvensional mengakibatkan produk tidak higienis karena produk yang tidak tertutup rapat. Produk-produk yang tidak tertutup rapat pada akhirnya tidak bisa dijual. (3) Kurangnya inovasi pada kemasan produk, hal ini terlihat dari tidak adanya keterangan manfaat produk dan tanggal kadar luarsa pada kemasan produk
Berikut adalah urutan acara pengabdian kepada masyarakat yang bertempat di Balai Warga Dusun Kedung Buweng kecamatan Wukirsari, Bantul- Yogyakarta. Tabel Acara PKM

\begin{tabular}{|c|l|l|}
\hline $\begin{array}{c}\text { N } \\
\mathbf{o}\end{array}$ & \multicolumn{1}{|c|}{ Materi } & Narasumber \\
\hline 1 & $\begin{array}{l}\text { Pembukaan } \\
\text { Kegiatan PKM }\end{array}$ & $\begin{array}{l}\text { Khotimatus } \\
\text { Sadiyah, S.Si, } \\
\text { M.M }\end{array}$ \\
\hline 2 & $\begin{array}{l}\text { Penjelasan tentang } \\
\text { Manajemen } \\
\text { Pemasaran }\end{array}$ & $\begin{array}{l}\text { Wiwik } \\
\text { Hasbiyah AN, } \\
\text { S.Hi, MA }\end{array}$ \\
\hline 3 & $\begin{array}{l}\text { Penjelasan tentang } \\
\text { Manajemen } \\
\text { Keuangan }\end{array}$ & $\begin{array}{l}\text { Julian } \\
\text { Muhammad } \\
\text { Hasan, } \\
\text { S.Sos.,M.A. }\end{array}$ \\
\hline 4 & Doa dan Penutup & $\begin{array}{l}\text { Dina Novita, } \\
\text { SE,M.M dan } \\
\text { Liana Dwi } \\
\text { Septiningrum, } \\
\text { S.E. , M.M. }\end{array}$ \\
\hline
\end{tabular}

Adapun Materi - materi yang diberikan adalah sebagai berikut:

1. Materi tentang Manajemen Pemasaran

Perkembangan Usaha Kecil dan Menengah di Indonesia terus berkembang dikarenakan pertumbuhan ekonomi yang terus meningkat. Perkembangan ini tentunya menuntut pelaku UKM untuk lebih kreatif dan inovatif dalam menyusun strategi pemasaran yang efektif. Sebuah UKM akan sulit untuk berkembang jika pelaku usahanya tidak mengetahui bagaimana cara memasarkan suatu produk dengan efektif. Berikut adalah beberapa strategi yang dapat digunakan untuk memasarkan bisnis UMKM Bangkit Sejahtera.

a. Membuat produk yang unik dan memiliki kelebihan.

Pesaing tentu ada di mana-mana, jika produk atau jasa yang ditawarkan tidak memiliki kelebihan, maka akan sulit untuk bersaing. Bukan hanya itu, selain unik dan berkualitas, produk yang ingin dijual juga harus bisa memenuhi kebutuhan konsumen. Seiring dengan perkembangan zaman dan teknologi, kebutuhan 
konsumen pun ikut berubah, oleh karena itu, inovasi harus selalu harus dilakukan secara berkala. Hal ini untuk membantu dalam persaingan pasar dan membuat pelanggan loyal terhadap produk yang dijual.

b. Menjadi Networker.

Networker adalah seseorang yang memiliki jaringan yang sangat luas dan memiliki sifat optimis dalam menjalankan bisnis. Jika Anda bukanlah seorang networker yang kompeten, Anda bisa mempekerjakan seorang tenaga pemasaran yang bisa diandalkan sebagai ujung tombak untuk perluasan jaringan UKM Anda.

c. Menentukan STP.

STP singkatan dari segmenting, targeting, dan positioning. Di mana tiga hal tersebut saling berhubungan satu sama lainnya. Untuk memasarkan UKM, menentukan segmentasi (segmenting) yaitu dengan menem] konsumen dalam sub-kelompok di produk, sehingga para pembeli $\mathrm{m} \epsilon$ tanggapan yang hampir sama $\dot{c}$ strategi pemasaran dalam pen posisi perusahaan. Jika telah meneı segmentasinya, selanjutnya menentukan pasar (targeting), di harus mengevaluasi berbagai $\mathrm{st}$ tersebut untuk memutuskan siapa menjadi target market. $S$ menentukan segmenting dan tars selanjutnya menentukan (positioning) produk yang meru kombinasi kegiatan pemasaran dilakukan manajemen untuk memenuhi kebutuhan dan keinginan setiap pasar sasaran. Ketiga strategi tersebut harus dilakukan dengan baik untuk mencapai pemasaran yang sukses.

d. Memanfaatkan E-commerce

Dengan memanfaatkan e-commerce, bisnis memiliki peluang untuk menjangkau pasar yang luas bahkan global. E-commerce dalam dunia bisnis dapat mendukung pemotongan rantai distribusi, sehingga konsumen dapat memperoleh suatu produk dengan harga murah. Pemasaran produk dengan ecommerce memiliki beberapa manfaat antara lain, murah dan efisien, memiliki akses tanpa batas, dan memperpendek jarak distribusi produk.

e. Konsisten

Konsistensi dalam menjalankan strategi pemasaran merupakan hal penting. Selain kreatif, pelaku UKM juga dituntut untuk bisa terus konsisten dalam menjalankan strategi pemasaran yang dipilih. Hal ini penting karena kepercayaan konsumen akan terbangun apabila pelaku usaha konsisten di bidang usaha yang digeluti dan menjadi seorang ahli didalamnya.

2. Materi tentang Manajemen Keuanagan Bagi UMKM “(Tips Membangun Manajemen Keuangan Bagi UMKM)

Manajemen Keuangan yang baik sangat penting untuk mempertahankan bisnis dari kondisi ekonomi yang tidak stabil dan persaingan bisnis. UMKM, terutama, perlu berhati-hati dengan keputusan keuangan mereka dari sejak awal berdiri. Dibutuhkan lebih dari sekadar ide inovatif untuk menjalankan bisnis. Setiap bisnis membutuhkan struktur keuangan yang menghasilkan laba agar tetap bias bertahan. Sehingga yang dibutuhkan pengusaha adalah kemampuan Manajemen Keuangan yang baik untuk membawa bisnis mereka menuju kesuksesan. Berikut tips untuk memaksimalkan cara membangun Manajemen Keuangan yang baik bagi UMKM:

a. Menghindari kredit mahal

Untuk membangun portofolio sukses yang menguntungkan di masa sekarang dan masa depan, tips pertama dan terpenting untuk mengelola keuangan usaha kecil adalah untuk menetapkan tujuan keuangan. Penggunaan dana yang optimal adalah kunci kesuksesan. Dalam periode pertumbuhan bisnis, biaya kredit sangat berpengaruh secara signifikan. Jangan sampai pengeluaran bisnis membengkak hanya karena harus melunasi pokok dan bunga utang. 
Disarankan, hindari pinjaman yang mempunyai nilai pokok mahal dan berbunga tinggi untuk menghindari kemungkinan gagal bayar. Tetapkan tujuan pemakaian keuangan bisnis dengan menekan pengeluaran dan meraih profitabilitas lebih awal.

b. Fokus pada hal-hal biaya Pada tahap awal memulai UMKM ataupun ketika sedang masa pertumbuhan bisnis, bijaksana untuk tetap menjaga biaya atau pengeluaran bisnis agar serendah mungkin. Ubah kebiasaan menghabiskan uang untuk berbagai biaya atau pengeluaran yang tidak penting dan tidak relevan bagi tujuan bisnis. Merencanakan anggaran selama periode satu tahun untuk pengeluaran besar seperti sewa, penggajian, pajak, bunga, Harga Pokok Penjualan, utang, utilitas, dan biaya operasional lainnya dapat membantu dalam mengurangi beban keuangan.

c. Pertahankan batas antara keuangan pribadi dan Usaha

Pemisahan keuangan bisa dengan membuat rekening pribadi dan bisnis secara terpisah. Menahan batas antara kedua jenis tabungan ini akan memberi penghitungan yang lebih mudah dan tepat pada akhir tahun keuangan. Ini juga akan menghilangkan situasi krisis uang kas dalam bisnis yang disebabkan karena penarikan untuk pengeluaran pribadi.

d. Evaluasai secara konsisten

Pelaku bisnis harus mengetahui ke mana saja aliran uang bisnis mengalir secara detail dan efisien untuk keperluan Manajemen Keuangan. Untuk itu, perlu adanya mempunyai Laporan Arus Kas bisnis untuk pencatatan keuangan. Evaluasi ini akan membantu menentukan area mana yang berkinerja paling efisien dan di sektor mana perlu mengendalikan dana

e. Bernegosiasi sebelum bekerjasama

Bernegosiasi dengan vendor sebelum menandatangani kontrak dan meminta penawaran terbaik adalah suatu keputusan yang cerdas dan bijak untuk manajemen keuangan UMKM. Negosiator yang sukses adalah orang yang mengetahui kebutuhan dan harga terbaik sebelum mereka mulai menegosiasikan apa yang ingin mereka dapatkan. Periksa syarat-syarat pembelian seperti denda keterlambatan pembayaran dan masa tenggang pelunasan pembelian. .

\section{KESIMPULAN DAN SARAN}

\section{Kesimpulan}

Kegiatan pelaksanaan Pengabdian Kepada Masyarakat (PKM) yang dilaksankan di balai warga Dusun Kedung Buweng Kecamatan Wukirsari, Kabuapaten Bantul - Yogyakarta pada hari Sabtu,12 Oktober 2019 s.d Senin, 14 Oktober 2019. dapat ditarik kesimpulan bahwa secara umum kegiatan pengabdian kepada masyarakat dapat terlaksana dengan baik dan mendapat sambutan dan dukungan dari UMKM Bangkit Sejahtera. Kegiatan PKM ini telah memberikan kontribusi kepada pelaku bisnis/ mitra bisnis dengan memberikan solusi berupa pelatihan guna meningkatkan pengetahuan dalam penggunaan sosial media sebagai infrastruktur pemasaran produknya.

\section{Saran}

Pengabdian masyarakat diharapkan dapat dilakukan kembali di dusun Kedung Buweng Wukirsari - Yogyakarta karena masih banyak anggota UMKM yang belum hadir secara penuh dikarenakan bekerja.

Diharapkan mitra bisnis dapat mengembangkan bisnis tidak hanya di satu gerai/ kedai saja namun juga didaerah atau tempat lain sehingga pangsa pasarnya berkembang.

\section{DAFTAR PUSTAKA}

Danang Sunyoto, Teori, Kuesioner dan analisis data untuk pemasaran dan perilaku konsumen, Yogyakarta, Graha Ilmu, 2013.

Daryanto, 2011.Manajemen Pemasaran : Sari Kuliah, Cetakan I, Satu Nusa,Bandung. 
Loyalitas Kreativitas

Aledi Masyarakat Kreatif
P-ISSN 2722-2101, E-ISSN 2722-4201

Program Studi Ekonomi Manajemen Universitas Pamulang Jurnal LOKABMAS Kreatif Vol. 01, No. 01, Hal. 36 - 49

Email:jurnalkreatif.manajemen@gmail.com
Dion Thohiron,"KarakteristikUMKM”, dalam http ://id. shvoong.com/

socialsciences/economics/2263514karakteristikumkm/\#ixzz2hIiTBQCT. (10 Oktober 2013).

Kotler dan Keller. 2009. Manajemen Pemasaran. Jilid I. Edisi ke 13. Jakarta:Erlangga

Kotler, Philip. 2010. Manajemen Pemasaran. Edisi tiga belas Bahasa Indonesia. Jilid 1 dan 2.Jakarta : Erlangga.

Oentoro, Deliyanti. 2010. Manajemen Pemasaran Modern. Yogyakarta: Laksbang Pressindo.

Pasaribu, V. L. D., Agrasadya, A., Shabrina, N., \& Krisnaldy, K. (2020). MENJADI ENTERPRENEUR MUDA YANG MEMILIKI JIWA LEADERSHIP UNTUK MENGHADAPI MASA DEPAN. Abdi Laksana, 1(1)

Pasaribu, V. L. D., Elburdah, R. P., Sudarso, E., \& Fauziah, G. (2020). PENGGUNAAN MANAJEMEN WAKTU TERHADAP PENINGKATAN PRESTASI BELAJAR DI SMP ARAISIYAH. Jurnal ABDIMAS, 1(1)

Pasaribu, V. L. D., Susanti, F., \& Hartuti, E. T. K. (2019). MEMOTIVASI SISWA DAN SISWI SMK LETRIS INDONESIA DI DALAM MENENTUKAN PILIHAN UNTUK MELANJUTKAN PENDIDIKAN ATAU BEKERJA SETELAH LULUS

SEKOLAH. Jurnal Pengabdian Dharma Laksana, 1(2), 161-172.

Peter, J. Paul dan Jerry C. Olson. 2000. Consumer Behavior. Perilaku konsumen dan Strategi Pemasaran. Jilid 2.Edisi 4. Jakarta: Erlangga.

Tim LPPM Pamulang. 2016. Buku Panduan Penelitian dan Pengabdian Kepada Masyarakat. Universitas Pamulang. Tangerang Selatan

Tjiptono, Fandy. 2008. Strategi Pemasaran, Edisi Ketiga. Andi, Yogyakarta
Website Kabupaten Bantul (https://wukirsari.bantulkab.go.id)

\section{DOKUMENTASI KEGIATAN}
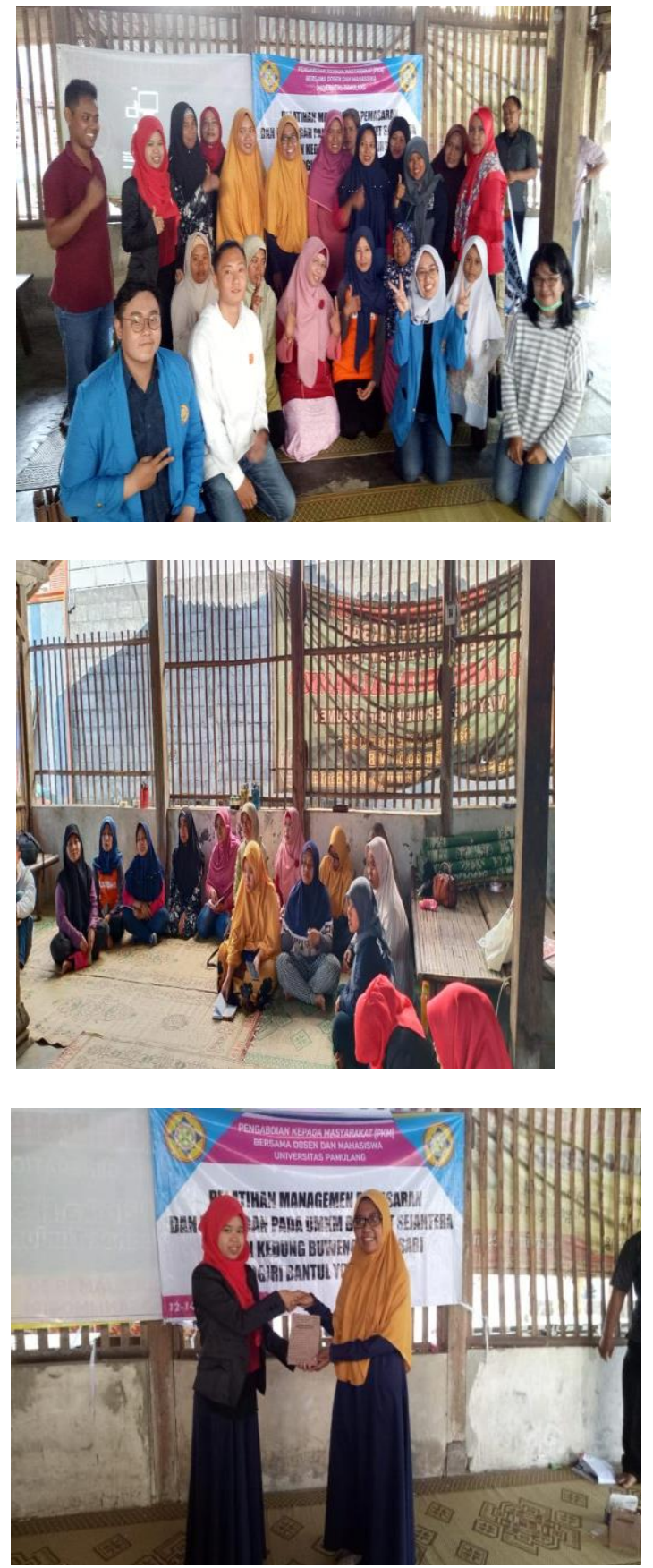
Loyalitas Kreativitas

Aldi Masyarakat Kreatif
P-ISSN 2722-2101, E-ISSN 2722-4201

Program Studi Ekonomi Manajemen Universitas Pamulang Jurnal LOKABMAS Kreatif Vol. 01, No. 01, Hal. 36 - 49

Email:jurnalkreatif.manajemen@gmail.com
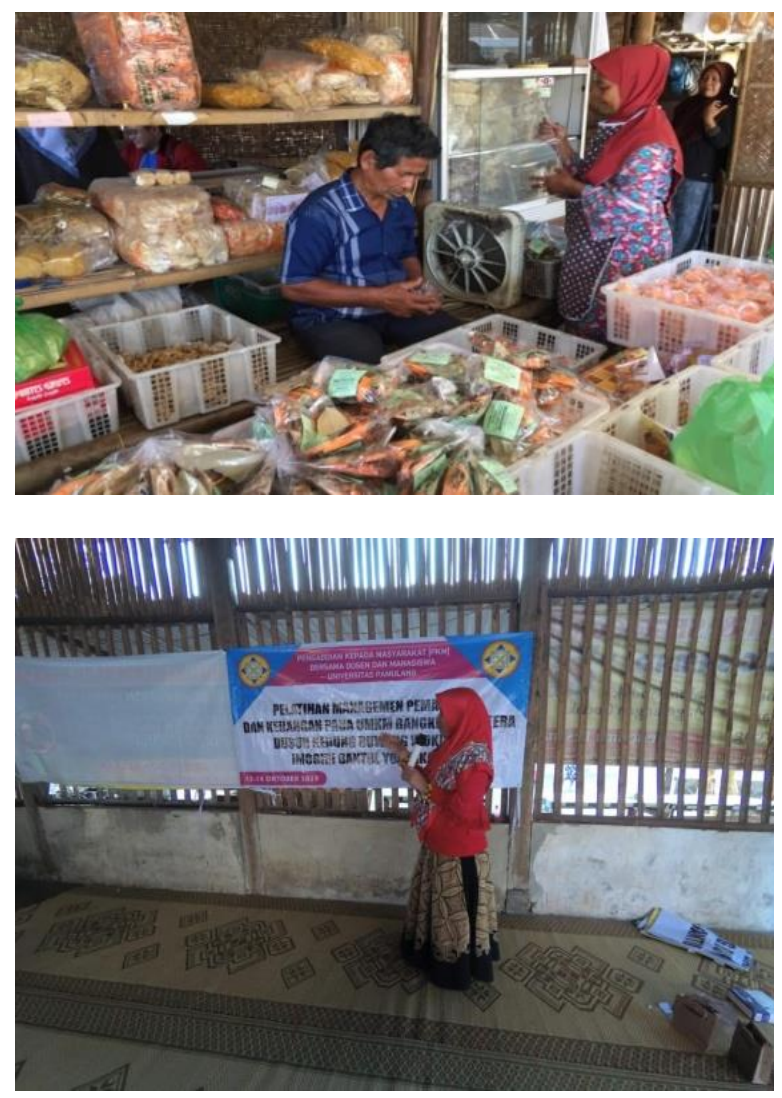